\title{
EQPac: A Process Study in the CENTRAL EQUatorial PACIFIC
}

By James W. Murray, Margaret W. Leinen, Richard A. Feely, J.R. Toggweiler and Rik Wanninkhof

E QPAC IS the United States-Joint Global Ocean Flux Study (US-JGOFS) process study in the central equatorial Pacific. The first EqPac cruises sailed in January 1992 during a moderately strong El Nino. This was fortuitous for our studies of chemical and biological distributions because $\mathrm{El}$ Nino events are difficult to predict, and the lead time for a project of this size is long. There was virtually no previous upper-water-column chemical or biological data for $\mathrm{El}$ Nino conditions in the central equatorial Pacific. Now an El Nino has been studied in considerable detail, and it will be easy to sample the extremes in environmental conditions by sampling non-El Nino conditions (including La Nina) in 1993 and the years thereafter. The implementation of EqPac illustrates how difficult it is to mount a large-scale interdisciplinary study of the ocean when the interannual variability is large.

The equatorial Pacific is one of the more-orless independent ocean "ecosystems" that have 1) characteristic trophic structure, 2) characteristic material cycles, and 3) recognizable boundaries (Barber, 1988). The region has distinct chemical and biological character compared with the tropical waters of the relatively barren, oligotrophic central gyres of the north and south Pacific. Upwelling of nutrient-rich water at the equatorial divergence in the Pacific supports a highly productive phytoplankton community that contributes significantly to global new production (Chavez and Barber, 1987). Vertical motion is constrained to within a degree of the equator (Halpern and Freitag, 1987), and surface divergence of the upwelled water results in a broader band of nutrient-

J.W. Murray, School of Oceanography, University of Washington, Seattle, WA 98195 , USA; M.W. Leinen, Graduate School of Oceanography, University of Rhode Island, Narragansett, RI 02882-1197, USA; R.A. Feely, NOAA Pacific Marine Environmental Laboratory, 7600 Sand Point Way NE, Seattle, WA 98115, USA; J.R. Toggweiler, NOAA Geophysical Fluid Dynamics Laboratory, Princeton University, Princeton, NJ 08542, USA; and R. Wanninkhof, NOAA Atlantic Oceanographic and Meterological Laboratory, 4301 Rickenbacker Causeway, Miami, FL 33149, USA. rich water. The resulting nutrient-rich swath straddles the equator and extends across the $\mathrm{Pa}$ cific basin to at least the dateline. Nutrients are the prime factor governing the large-scale pattern of spatial heterogeneity in productivity of the contemporary ocean and thus also the long-term temporal variations observed in the sedimentary record.

Until recently primary production in the equatorial Pacific was thought to be supported chiefly by the upwelling of "new nutrients" (Chavez and Barber, 1987), such as nitrate $\left(\mathrm{NO}_{3}^{-}\right)$as defined by Dugdale and Goering (1967). The new production, driven by these new nutrients was thought to be a large proportion of the total primary production. In oligotrophic regions of the ocean, "regenerated production" driven by nutrients such as ammonia $\left(\mathrm{NH}_{4}^{+}\right)$and urea is most important. However, the phytoplankton biomass and primary productivity in the equatorial Pacific are not as high as the flux of nutrients could potentially support.

Primary productivity controls many oceanographic biogeochemical processes. Thus, a key to understanding the present and past ocean carbon cycles is to learn the factors that regulate primary and new productivity in this environment and to learn why the equatorial region is not "greener" and more productive (Barber, 1992a).

\section{Previous Studies}

The central equatorial Pacific was chosen for EqPac for two reasons: 1) the processes that control primary and new productivity and 2) scale and global mass balances.

Understanding the basic controls or master variables that determine the spatial heterogeneity and magnitude of primary and new productivity is one of the main goals of US-JGOFS (USJGOFS, 1990). Macronutrients (e.g., $\mathrm{NO}_{3}^{-}$) and grazing have long been thought to determine existing large-scale patterns of productivity. Some recent work has shown that the problem is not so simple. For example, Murray et al. (1989) showed that surface $\mathrm{NO}_{3}^{-}$was a poor predictor of the re- 
gional pattern of primary and new productivity in the eastern equatorial Pacific. In addition, the magnitude of primary and new production was anomalously low compared with the nutrient levels present. These observations also apply to the central equatorial Pacific (Cullen et al., 1992) and lead to the question, why?

From the standpoint of chemical and biological oceanography, the equatorial Pacific's most distinguishing feature is the huge tongue of low-temperature, high-nutrient, high- $\mathrm{PCO}_{2}$ water that extends from the eastern boundary to the dateline. A zonal section of temperature, nitrate, and chlorophyll on the equator is shown in Figure 1 (Chavez and Brusca, 1991). Maps of model-predicted surface $\mathrm{NO}_{3}^{-}$for the fall and spring seasons are shown in Figure 2. There is a progressive decrease in temperature and an increase in $\mathrm{NO}_{3}^{-}$ eastward from the date line. Chlorophyll is slightly elevated, compared with adjacent ocean regions but shows no systematic east-west gradients.

The basin-scale distribution of ocean pigment, inferred from Coastal Zone Color Scanner (CZCS) images has given us the best indication of the seasonal variability and has allowed us to select features that should be sampled (e.g., high pigment near $9^{\circ} \mathrm{N}$ ) and those that should be avoided (island effects at $9^{\circ} \mathrm{S}, 140^{\circ} \mathrm{W}$ ) (see Feldman et al., 1992 , this issue). Observations that go back to at least 1969 (Barber and Ryther, 1969) have shown anomalous chlorophyll and productivity patterns (e.g., Walsh, 1976; Thomas, 1979; Chavez and Barber, 1987; Pena et al., 1990; Cullen et al., 1991). In addition, the food web is dominated by small phytoplankton (Chavez, 1989) with a unique taxonomic composition dominated by relatively few groups in the pico- $(0.2-2 \mu \mathrm{m})$ and nanoplankton $(2-20 \mu \mathrm{m})$ size ranges (Chavez et al., 1990).

There are several possible explanations for the nutrient and productivity distributions, but grazing control (e.g.. Walsh. 1976: Banse, 1992; Cullen et al., 1992) and iron limitation (e.g.. Martin et al., 1989) have received most attention. Frost and Franzen (1992) used a simple chemostat model to show that grazing control is essential to reproduce the present conditions of high nutrients. low phytoplankton biomass, and high phytoplanktonspecific growth rate observed in the equatorial upwelling zone. Iron limitation is hypothesized to play a dual role by limiting nutrient utilization and influencing plankton species composition (Price et al., 1991). For example, large diatoms. which have elevated iron requirements. are one of the main groups conspicuously absent from the equatorial food web. The iron deficiency appears to be more pronounced east of $\sim 140^{\circ} \mathrm{W}$. where the rate of primary productivity is independent of the subsurface nutrient composition (Barber and Chavez, 1991). Low supply of eolian iron to this remote location may be the explanation.

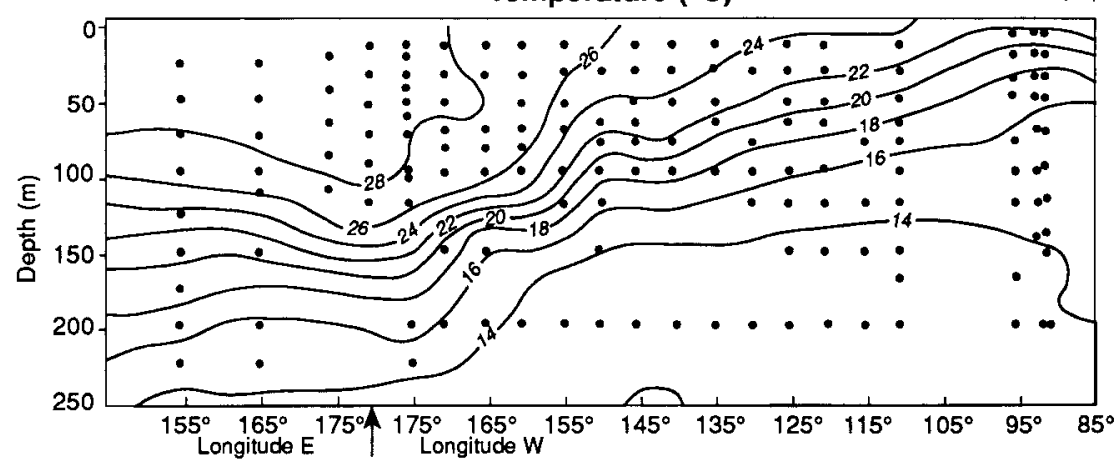

Nitrate $(\mu \mathrm{M})$

(B)

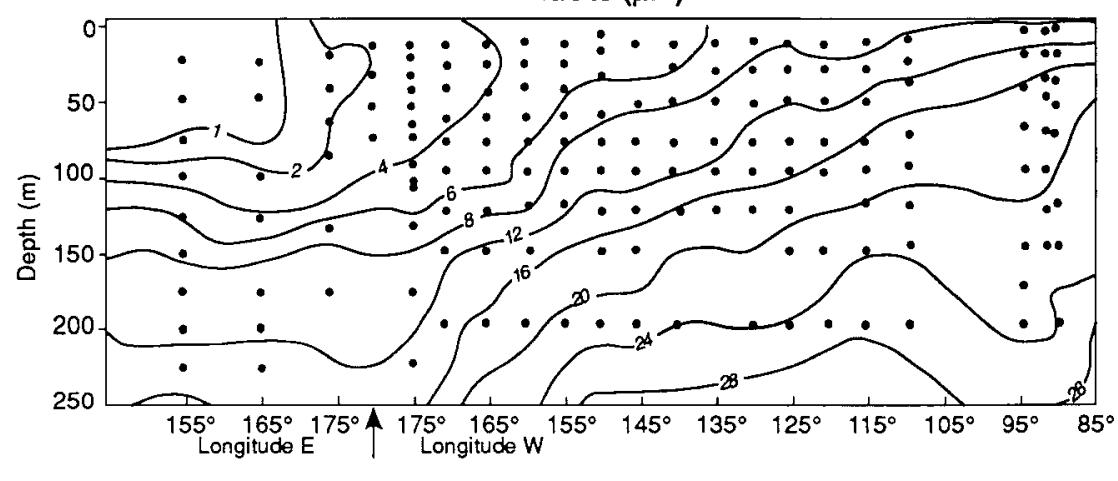

Chlorophyll $\left(\mathrm{mg} / \mathrm{m}^{3}\right)$

(C)

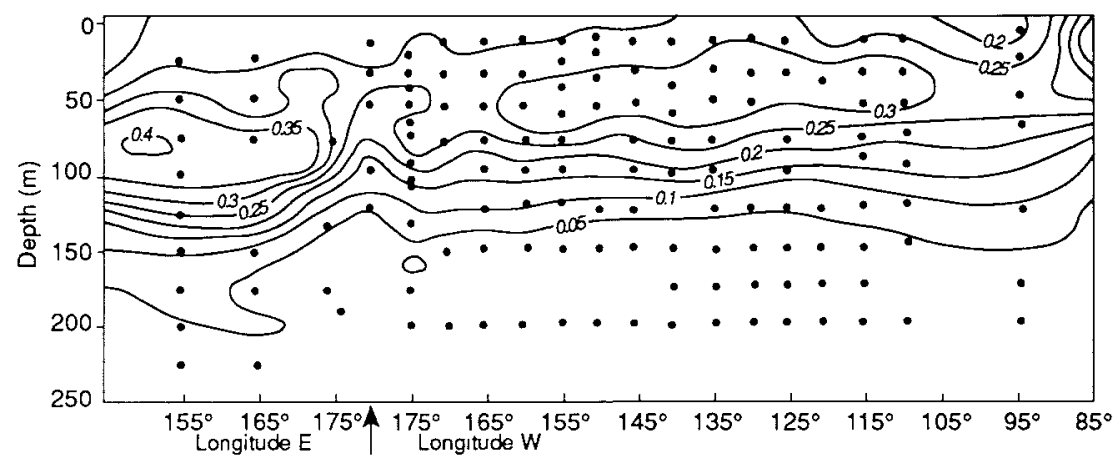

Fig. 1: Zonal sections of $(\boldsymbol{A})$ temperature, $(\boldsymbol{B})$ nitrate, and $(\boldsymbol{C})$ chlorophyll on the equator in the Pacific from $145^{\circ} \mathrm{E}$ to $85^{\circ} \mathrm{W}$ (Chavez and Brusca, 1991). The thermocline and nutricline shoal east of the date line, and the chlorophyll concentrations remain relatively uniform.

Other large ocean areas such as the southern ocean (Mitchell et al., 1991) and sub-arctic Pacific (Miller et al., 1991) have been shown to have similar nutrient-productivity relationships. These regions are referred to as having high-nutrient, lowchlorophyll (HNLC) distributions (Chisholm and Morel. 1991; Cullen, 1991). An important longrange goal of US-JGOFS will be to see whether we can generalize the results of EqPac to these other regions.

The equatorial Pacific plays a significant role in global carbon balances, because it is such a large area of the world ocean. Calculations by Chavez and Barber (1987) showed that the equatorial Pacific has the potential to produce as much as 1.9 gigatons ( $1 \mathrm{Gt}=10^{12}$ metric tons) new production
... grazing control and

iron limitation have

received most

attention. 

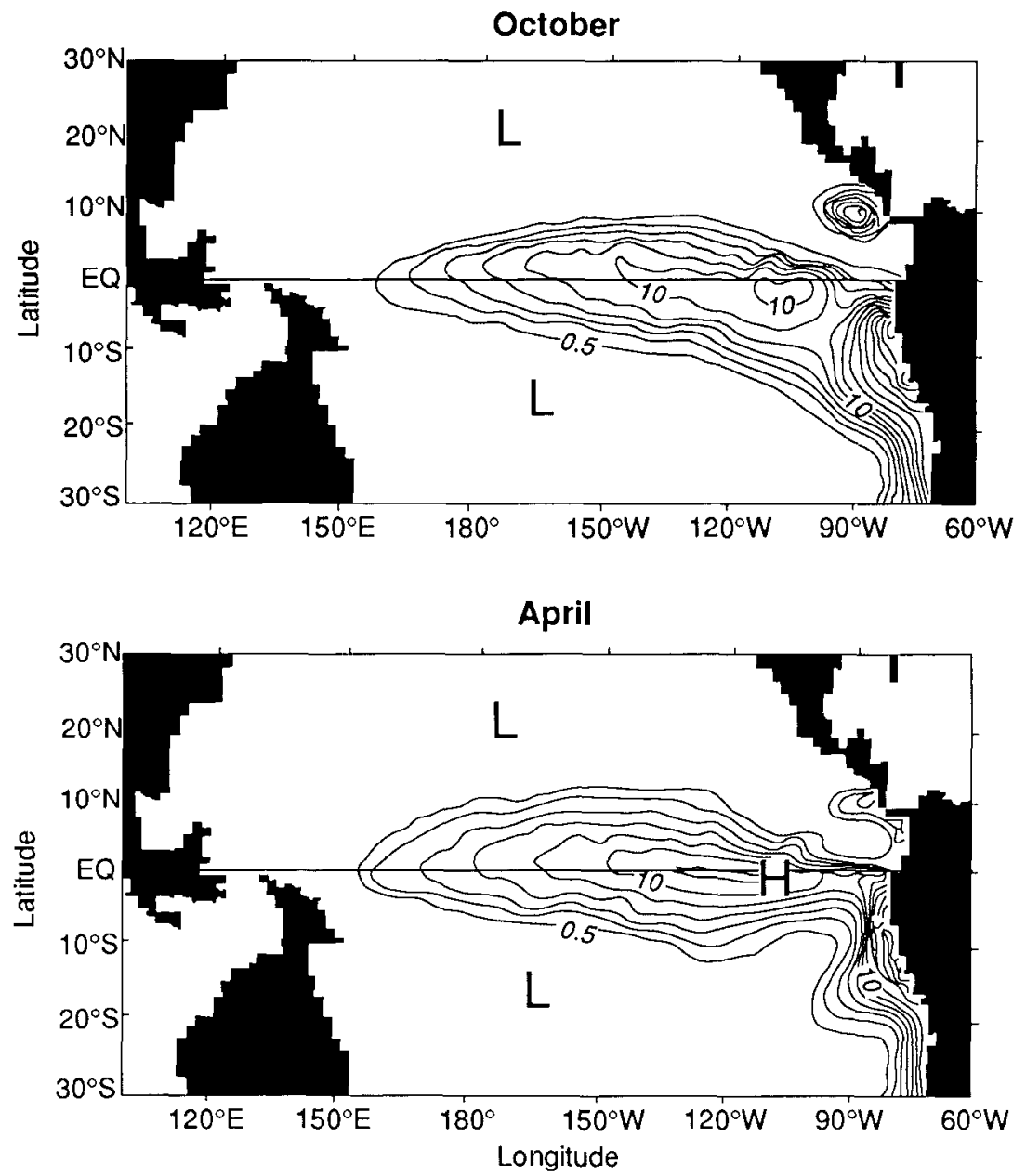

Fig. 2: Charts of surface nitrate ( $\mu M)$ during the months of October (top) and April (bottom) in the surface water of the tropical Pacific as predicted from the Princeton/Geophysical Fluid Dynamics Laboratory three-dimensional model that couples physical circulation, biochemical cycling, and food-web dynamics (J.R. Toggweiler, H.W. Ducklow. J.L. Sarmiento, and R. Slater, personal communication).

|timately carbon

fixed in surface waters is recycled. . per year. This would be a significant fraction of the global new production, estimated by Eppley and Peterson (1979) to be between 3.4 and 4.7 gigatons per year.

The cold tongue of upwelled water in the equatorial Pacific is characterized by high partial pressures of $\mathrm{CO}_{2}\left(\mathrm{PCO}_{2}\right)$ (Keeling, 1968). It is the largest natural source of $\mathrm{CO}_{2}$ to the atmosphere, if $\mathrm{CO}_{2}$ sources are averaged over an annual cycle (0.6 to $1.0 \mathrm{Gt}^{-1}$ ) (Gammon et al., 1985; Feely et al., 1987). Major spatial and temporal gaps in knowledge about the distributions of $\mathrm{CO}_{2}$ in surface waters need to be filled (Murphy et al., 1991). Finally, simple mass-balance calculations suggest that much of the carbon fixed by primary productivity may ultimately be exported from the region as dissolved organic carbon (DOC) (Bacastow and Maier-Reimer, 1991; Najjar et al., 1992). Barber and Ryther (1969) observed that recently upwelled water was lower in DOC than the water to the north and south, although the horizontal gradients were small. Their surface DOC values $(66 \mu \mathrm{m} / 1)$ are about one-half those recently reported by Martin and Fitzwater (1992) but are consistent with those reported from north of $\mathrm{Ha}$ waii by Benner et al. (1992). Evaluating the importance of DOC export will allow us to determine the role of the equatorial Pacific in global carbon budgets.

Ultimately carbon fixed in surface waters is recycled to the atmosphere, back into seawater, or is buried in sediments. Studies of the factors controlling burial will allow us to understand the sedimentary record of carbon burial. This, in turn, will allow us to study the response of ocean productivity to global climate change. Organic carbon and biogenic silica in surface sediments have higher concentrations at the Equator (Cwienk and Leinen, 1985; Fig. 3). The geological record in the underlying sediments contains a detailed, but complicated, history of how this system has changed in the geological past (e.g., Pedersen, 1983; Lyle et al., 1988; Pisias and Rea, 1988). This record represents $\sim 0.1 \%$ of the carbon originally fixed by photosynthesis that is not recycled in the water column or at the sediment-water interface. Benthic fluxes from $15^{\circ} \mathrm{S}$ to $11^{\circ} \mathrm{N}$ at $135^{\circ} \mathrm{W}$ are $\sim 1-2 \%$ of the primary production (Martin et al., 1991). The zonal variation in organic-carbon degradation rates was similar to the surface-water pattern of primary production. The rates for silica degradation were significantly different, perhaps due to differences in the composition of the particulate flux (e.g., diatom abundance). Sediment mixing by benthic deposit feeders plays an important role in organic carbon diagenesis and Smith (1992) has predicted that a 10 -fold decrease in bioturbation rate occurs between the Equator and $10^{\circ} \mathrm{N}$ at $140^{\circ} \mathrm{W}$. Calcium carbonate preservation has varied significantly over geological time (Farrell and Prell, 1989), and this may be due to variations in primary productivity and the organic-carbon rain rate (Archer. 1991).

The circulation of the equatorial Pacific is complicated but has been studied intensely as part of the Hawaii-Tahiti Shuttle (NORPACS) and the Tropical Ocean Global Atmosphere (TOGA) studies called Equatorial Pacific Ocean Climate Study (EPOCS), Tropic Heat and Tropical Atmosphere-Ocean (TAO). The physical circulation models for the equatorial Pacific are among the best and most realistic of any ocean region. The design of EqPac was influenced by a three-dimensional model for the equatorial Pacific that coupled circulation, biochemical cycling and foodweb dynamics. In this exercise a seven compartment version of the Fasham et al. (1990) foodweb model was imbedded in the Philander et al. (1987) equatorial Pacific circulation model. The coupled model predicts phytoplankton biomass and primary production as a function of in situ 
Organic Carbon (wt\% carbonate and opal free)

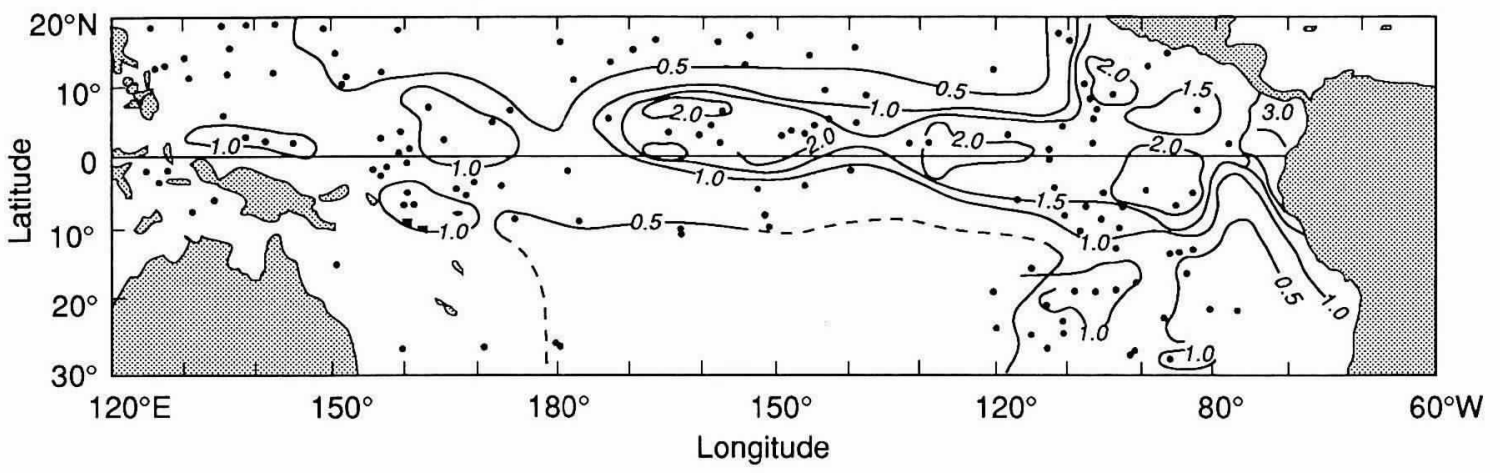

Biogenic Silica (wt\% carbonate free)

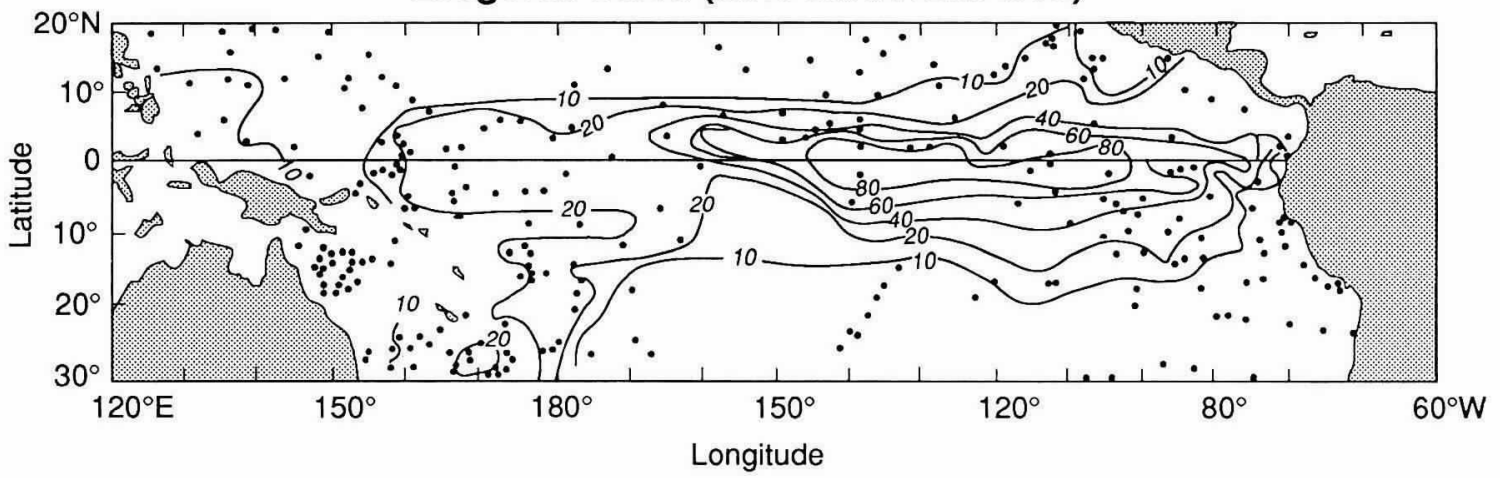

There is virtually no biological data . . . for El Nino conditions.

Fig. 3: Organic carbon and biogenic silica concentrations in equatorial Pacific surface sediments (Cwienk and Leinen, 1985).

irradiance and nutrient availability. The seasonal changes in surface nitrate concentrations predicted by the model are especially evident at $\sim 110^{\circ} \mathrm{W}$ (Fig. 2). The cruise tracks of the National Oceanic and Atmospheric Administration (NOAA) component have been designed to verify this predicted difference (Fig. 4).

There is significant interannual variability in surface temperature and nutrients associated with the El-Nino-Southern Oscillation (ENSO) (Enfield, 1989). There is virtually no biological data from the central equatorial Pacific for El Nino conditions. A set of biological data collected from $2^{\circ} \mathrm{N}$ to $2^{\circ} \mathrm{S}$ along $95^{\circ} \mathrm{W}$ by Barber and Kogelschatz (1990) during the $82 / 83 \mathrm{El} \mathrm{Nino} \mathrm{found} \mathrm{that}$ the primary and new productivity were drastically reduced. Some chemical data were reported for the 82/83 El Nino by Feely et al. (1987). They observed that the calculated net flux of $\mathrm{CO}_{2}$ across the air-sea interface was essentially zero during that period. Dymond and Collier (1988) observed that the biogenic particle fluxes to the deep sea were greatly reduced at the Equator during the $82 / 83$ El Nino. They were anomalously high at $11^{\circ} \mathrm{N}$ during this same period.

Based on previous observations, we expected the following scenario for a "typical" strong El Nino (after Feely et al., 1987; Barber and Kogelschatz, 1990; Siegenthaler, 1990; Barber, 1992b).
The equatorial trade winds are still easterly and strong in the central Pacific and upwelling continues from the 50- to $100-\mathrm{m}$ depth range. The sea-surface temperatures (SST) are elevated and the thermocline is depressed compared with non-

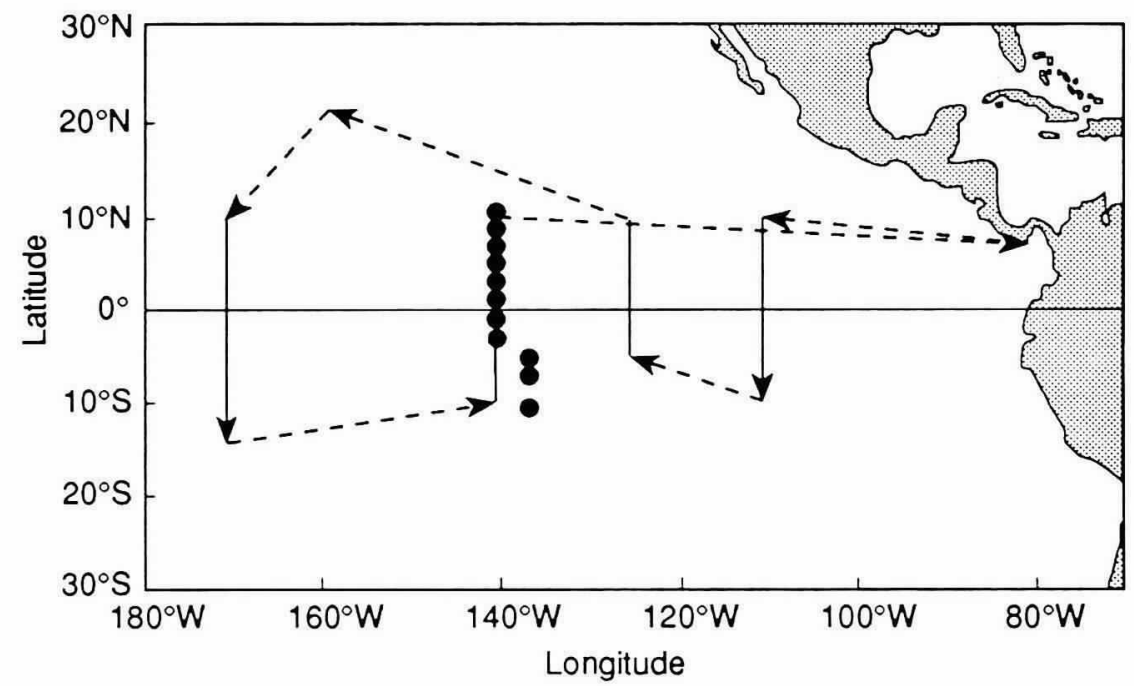

Fig. 4: Tentative EqPac station locations. The solid symbols along $140^{\circ} \mathrm{W}$ show the station locations of the NSF Survey Cruise. The NSF Time-Series cruise will spend most of its station time at the equator. The dashed and solid lines show the cruise track of the R/V Baldridge in the spring of 1992. In the fall of 1992 the meridional section at $170^{\circ} \mathrm{W}$ will be moved to $95^{\circ} \mathrm{W}$. 
1. To determine how large a role the equatorial Pacific plays in global biogeochemical cycles. (NSF and NOAA)

2. To determine the relationship between environmental variables (e.g., temperature, nitrate, and light) and the structure of the biological food web and the magnitude of primary and new productivity. (NSF)

3. To evaluate how midwater, deep-water, and benthic processes control the recycling of carbon and related elements and determine the ultimate removal of biological components to the deep ocean and burial in marine sediments. (NSF)

4. To determine how the region responds to interannual variability (El Nino, La Nina, etc.). (NSF and NOAA)

5. To construct budgets for carbon and nitrogen and evaluate the role of dissolved organic carbon and nitrogen (DOC/DON) and sinking particle fluxes in the biochemimical cycles. (NSF and NOAA)

6. To establish a three-dimensional understanding of how carbon and nitrogen enter and leave the equatorial region by combining multiple meridional sections together with coupled physical-circulation and biological-food-web models. (NOAA)

The NSF cruises

focus on the region

around $140^{\circ} \mathrm{W} \ldots$
El Nino conditions, due to migration of a Kelvin wave from west to east. Surface $\mathrm{NO}_{3}^{-}$is lower than normal because upwelling delivers warm nutrientdepleted water. Chlorophyll is lower than normal and, as a result, the euphotic zone is deeper. Primary production and new production may only be 25 and $5 \%$ of their normal values, respectively. There may be major changes in the phytoplankton species assemblages with decreased abundance of diatoms and increased coccolith concentration. The flux of $\mathrm{CO}_{2}$ to the atmosphere is close to zero or at least much less than its normal value. Because of the fortuitous timing of the 91/92 El Nino, EqPac will be able to verify whether these predictions are valid.

\section{Planning}

When the first EqPac sediment-trap-deployment cruise departed Honolulu on January 12, 1992, it had been almost four years since the USJGOFS Pacific Planning Meeting in Monterey during February 1988. The reports presented during that workshop (US-GOFS, 1989) and input from a large number of interested scientists led to the development of a science plan for the process study (Leinen and Murray, 1990). Approval from both the JGOFS and US-JGOFS steering committees in January 1990 followed these preliminary plans. The process study evolved to include components supported by both National Science Foundation (NSF) and Na-tional Oceanic and Atmospheric Administration (NOAA). The proposal solicitation for both NSF and NOAA was open with the only stipulation being that the problems and hypotheses in the EqPac science plan be addressed. The entire planning process benefitted greatly from the experiences of the JGOFS pilot study in the North Atlantic, called the North Atlantic Bloom Experiment (NABE) (US GOFS, 1986).

\section{Field Program}

The EqPac Science Plan (Leinen and Murray, 1990) addressed the goals shown (Table 1) by identifying seven scientific problems (Table 2). Each of these problems is the focus of several alternative hypotheses that will be tested as part of both the NSF and NOAA components of EqPac. The scope is wide ranging-from the euphotic zone, through the upper and deep water column to the sediments.

The NSF strategy is a detailed process-oriented investigation at a few locations. The NOAA component addresses some questions on a regional scale. As a result, the NSF and NOAA cruise plans are different (Table 3; Fig. 4). The NSF ship schedule on the Research Vessel Thompson consists of survey, time-series and benthic cruises as well as the moored-sediment-trap recovery in 1993. Moored sediment traps were deployed from a separate cruise on the Research Vessel Wecoma. The NSF cruises focus on the region around $140^{\circ} \mathrm{W}$ from $12^{\circ} \mathrm{N}$ to $12^{\circ} \mathrm{S}$ (Fig. 4). The station latitudes for the survey cruises are $12^{\circ}, 9^{\circ}, 7^{\circ}, 5^{\circ}$, $3^{\circ}, 2^{\circ}$, and $1^{\circ} \mathrm{N}$, and $0^{\circ}, 1^{\circ}, 2^{\circ}, 3^{\circ}, 5^{\circ}, 7^{\circ}, 9^{\circ}$, and $12^{\circ} \mathrm{S}$. The stations south of $5^{\circ} \mathrm{S}$ are moved to $135^{\circ} \mathrm{W}$ to avoid island effects (see Feldman et al., 1992). The time-series cruise will spend $\sim 18$

Table 2

Scientific problems to be addressed by EqPac (Leinen and Murray, 1990)

1. What is the relationship between physical forcing and upper ocean biogeochemical cycles?

2. Why are the levels of primary productivity and chlorophyll lower than expected based on ambient nutrient levels?

3. Why does the magnitude of the import and export for new productivity appear to be lower than expected based on ambient nutrient levels?

4. What are the processes responsible for transport and regeneration of particulate and dissolved nutrients?

5. What are the processes responsible for the formation and transport of dissolved organic matter?

6. What are the relationships of seafloor remineralization and burial rates to primary and new production?

7. What is the response of equatorial Pacific circulation and productivity to short- and long-term climate change? 
Table 3

1992 EqPac cruise schedule showing both NSF and NOAA sponsored cruises

\begin{tabular}{lllr}
\hline \multicolumn{1}{c}{ Cruise } & \multicolumn{1}{c}{ Chief Scientist } & \multicolumn{1}{c}{ Ports } & Dates \\
\hline Research Vessel Thomas G. Thompson (NSF) & & \\
Spring Survey & J.W. Murray (University of Washington) & Honolulu-Papeete & $1 / 29-3 / 13$ \\
Spring Time-Series & M. Roman (Horn Point Environmental Lab.) & Papeete-Honolulu & $3 / 17-4 / 20$ \\
Fall Survey & R.T. Barber (Duke University) & Honolulu-Papeete & $8 / 5-9 / 18$ \\
Fall Time-Series & M. Bacon (Woods Hole Oceanographic Lab.) & Papeete-Papeete & $9 / 22-10 / 25$ \\
Benthic & M. Leinen (University of Rhode Island) & Papeete-Honolulu & $10 / 29-12 / 12$ \\
Trap Recovery & R. Collier (Oregon State University) & to be scheduled in early 1993
\end{tabular}

Research Vessel Wecoma (NSF)

Trap Deployment

J. Dymond (Oregon State University)

Honolulu-Honolulu

$1 / 2-2 / 2$

Research Vessel Baldridge (NOAA)

Spring Leg 1

R. Wanninkhof (Atlantic Oceanographic and Meteorological Lab.)

Spring Leg 2

D. Atwood (Atlantic Oceanographic and Meteorological Lab.)

Spring Leg 3

R. Feely (Pacific Marine Environmental Lab.)

Balboa-Honolulu

$2 / 17-3 / 19$

Honolulu-Papeete

$3 / 25-4 / 10$

Papeete-Balboa

$4 / 16-5 / 17$

Research Vessel Discoverer (NOAA)

Fall Leg 2

Fall Leg 3

Fall Leg 4

Fall Leg 5
TBA

R. Feely (Pacific Marine Environmental Lab.)

R. Wanninkhof (Atlantic Oceanographic and Meteorological Lab.)

P. Murphy (Atlantic Oceanographic and Meteorological Lab.)

$\begin{array}{lr}\text { Hilo-Hilo } & 8 / 3-8 / 27 \\ \text { Hilo-Manzanillo } & 9 / 3-10 / 5 \\ \begin{array}{l}\text { Manzanilla- } \\ \quad \text { Panama }\end{array} & 11 / 16-12 / 10 \\ \text { Panama-Seattle } & 10 / 12-11 / 10\end{array}$

days at the equator. This is approximately the time scale of the tropical instability waves. The extremes in physical forcing occur in the boreal spring and fall, so the cruise plan has a survey cruise from $12^{\circ} \mathrm{N}$ to $12^{\circ} \mathrm{S}$ and a time-series cruise near the equator in approximately both seasons. This approach will evaluate the variability in carbon cycling due to seasonal forcing. There will be one benthic cruise in November 1992 that will take advantage of the year-long record of deepocean sediment-trap fluxes that will precede the benthic-flux measurements on that cruise. Sediment-trap and benthic-cruise stations are at $9^{\circ}$, $5^{\circ}$, and $2^{\circ} \mathrm{N}, 0^{\circ}, 2^{\circ}, 5^{\circ}$, and $12^{\circ} \mathrm{S}$. The $12^{\circ} \mathrm{S}$ station is at $135^{\circ} \mathrm{W}$ and all the rest are at $140^{\circ} \mathrm{W}$.

The NOAA cruises on the $\mathrm{R} / \mathrm{V}$ Baldridge in the spring and the $\mathrm{R} / \mathrm{V}$ Discoverer in the fall will make four crossings of the equator (Fig. 4). In the fall the section at $170^{\circ} \mathrm{W}$ will be moved to $95^{\circ} \mathrm{W}$ to investigate seasonal differences in the distribution of carbon and nitrogen species to the south and into the Peru upwelling region (Fig. 2).

The project's principal investigators (PIs) and research programs for the NSF component and NOAA component are shown in Tables 4 and 5 . respectively. There are a total of 53 PIs in the NSF component and 10 PIs in the NOAA component.

Three additional projects that are closely associated with EqPac will be conducted in the equatorial Pacific region at $140^{\circ} \mathrm{W}$. Drs. Frank Hoge of The National Atmospheric and Space Administration (NASA) and James Yoder (University of Rhode Island) have organized longrange $\mathrm{P} 3 \mathrm{~B}$ aircraft overflights of the study area for late August 1992. These flights have been scheduled to coincide with the period when the Thompson will be on station at the equator. In the absence of an ocean-color satellite the aircraft sensors will provide snap-shots of the regionalscale distribution of chlorophyll, phycoerythrin, dissolved-organic-matter fluorescence, passive upwelled irradiance, and sea-surface temperature. Drs. John Martin (Moss Landing Marine Laboratory) and Neil Tindale (University of Rhode Island) have organized an Office of Naval Research (ONR) sponsored study of atmospheric dust sources of iron and their effect on ocean primary productivity. Atmospheric dust samples will be collected on the Research Vessel Wecoma and transferred to the Research Vessel Thompson for seawater enrichment experiments during the spring time-series cruise. Finally, Drs. Tim Bates (NOAA/Pacific Marine Environmental Lab) and Eric Saltzman (University of Miami) are coordinating a NOAA/NSF-sponsored study of atmospheric and ocean carbon, nitrogen, and sulfur trace-gas chemistry at $2^{\circ}$ and $12^{\circ} \mathrm{S}$. This cruise will overlap with the EqPac spring survey cruise.
The NOAA cruises

... will make four

crossings of the

equator. 
Table 4

NSF-sponsored EqPac principal investigators and topics of research

Survey cruises

James Murray (University of Washington)

Jan Newton (University of Washington) John Hedges (University of Washington) Paul Quay (University of Washington) Jim Swift (Scripps Institution of Oceanography)

Dick Barber (Duke University Marine Lab.)

Jim McCarthy (Harvard University)

Chris Garside (Bigelow Laboratory)

Jim Bishop (Lamont-Doherty Geological Laboratory)

Dave Archer (Lamont-Doherty Geological Laboratory)

Chuck Trees (San Diego State University)

Jim Aiken (Plymouth Marine Lab.)

Bob Bidigare (University of Hawaii)

Mike Landry (University of Hawaii)

Dave Kirchman (University of Delaware)

T.-L. Ku (University of Southern California)

Hans Dam (University of Connecticut)

Mike Roman (Horn Point Environmental Lab.)

Edward Peltzer (Woods Hole Oceanographic Institution)

Greta Fryxell (Texas A\&M University)

Barney Balch (University of Miami)

Time-series cruises

Mike Bacon (Woods Hole Oceanographic Institution)

Catherine Goyet (Woods Hole Oceanographic Institution)

Robert Olson (Woods Hole Oceanographic Institution)

Penny Chisolm (Massachusetts Institute of Technology)

Kirk Cochran (State University of New York)

Dick Barber (Duke University)

Michael Bender (University of Rhode Island)

Michael Sieraki (Bigelow Laboratory for Ocean Sciences)

Peter Verity (Skidaway Institute of Oceanography)

Diane Stoecker (Horn Point Environmental Lab.)

Mike Roman (Horn Point Environmental Lab.)

Hans Dam (University of Connecticut)

Hugh Ducklow (Horn Point Environmental Lab.)

Pat Wheeler (Oregon State University)

Jim Swift (Scripps Institution of Oceanography)

Curtis Davis (Jet Propulsion Lab.)

Mike Landry (University of Hawaii)

Bob Bidigare (University of Hawaii)

Alan Mix (Oregon State University)

Wilf Gardner (Texas A\&M University)

Mary Jo Richardson (Texas A\&M University)

Ian Walsh (Texas A\&M University)

Vernon Asper (University of Southern Mississippi)

Greta Fryxell (Texas A\&M University)

John Martin (Moss Landing Marine Lab.)

James Murray (University of Washington)

\section{Benthic Cruise}

Margaret Leinen (University of Rhode Island)

Doug Hammond (University of Southern California)

Will Berelson (University of Southern California)

Dave DeMaster (North Carolina State University)

Craig Smith (University of Hawaii)

Fred Dobbs (University of Hawaii)

Bob Anderson (Lamont-Doherty Geological Observatory)

Cindy Lee (State University of New York)

Dave Kadko (University of Miami)

John King (University of Rhode Island)

Kuo Yen Kuei (Yale University)

\section{Moored Sediment Trap Cruises}

Bob Collier (Oregon State University)

Jack Dymond (Oregon State University)

Nick Pisias (Oregon State University)

Susumo Honjo (Woods Hole Oceanographic Institution)

Stuart Wakeham (Skidaway Institute of Oceanography)

\section{Hydrography}

Floating traps, flux of scavenging isotopes and trace elements

Floating traps, flux of $\mathrm{C}, \mathrm{N}, \mathrm{P}$, and pigments, growth rates

Floating traps, flux of organic compounds

Stable carbon isotopes

Salinity and oxygen

Primary productivity using ${ }^{14} \mathrm{C}$

Nitrogen cycling and new productivity using ${ }^{15} \mathrm{~N}$

Nitrogen cycling, core nutrients and pump profiling

In situ pump filtration, elemental composition of particulate matt

Carbonate system analyses $\left(\mathrm{PCO}_{2}\right.$, total $\mathrm{CO}_{2}$, and alkalinity)

In situ optics

In situ optics

Biological tracer pigments by high-pressure liquid chromatography Microzooplankton biomass and grazing rates

Bacterial biomass and production

Th and Be isotopes

Mesozooplankton biomass and grazing rates

Mesozooplankton biomass and grazing rates

Dissolved-organic-carbon analyses

Plankton speciation

Calcification

In situ pump filtration and scavenging isotopes

Carbonate system analyses $\left(\mathrm{PCO}_{2}\right.$, Total $\mathrm{CO}_{2}$, and alkalinity)

Cyanobacteria, prochlorophytes

Cyanobacteria, prochlorophytes

In situ pump filtration and scavenging isotopes

Primary productivity using ${ }^{14} \mathrm{C}$

Gross primary production using oxygen isotopes

Microzooplankton biomass and grazing rates

Microzooplankton biomass and grazing rates

Microzooplankton biomass and grazing rates

Mesoplankton biomass and grazing rates

Mesoplankton biomass and grazing rates

Bacterial biomass and production

Nitrogen cycling using ${ }^{15} \mathrm{~N}$, core nutrients

Salinity and oxygen

In situ optics

Microzooplankton grazing

Biological tracer pigments

Stable carbon isotopes

Particulate matter and aggregate studies

Particulate matter and aggregate studies

Particulate matter and aggregate studies

Particulate matter and aggregate studies

Plankton speciation

Iron-enrichment experiments, trace-metal profiles

Hydrography

Sediment composition and deposition rates

Benthic fluxes

Benthic fluxes

Sediment/water interface: isotope studies

Sediment/water interface: benthic biology

Sediment/water interface: benthic biology

Sedimentary radionuclides

Organic-matter diagenesis and burial fluxes

Sedimentary radionuclides

Sedimentary accumulation rate

Paleoceanography

Moored sediment traps

Moored sediment traps

Settling foraminifera

Moored sediment traps

Flux of particulate organic compounds

In addition, Mark Altabet (Woods Hole Oceanographic Institution) and Miriam Kastner (Scripps Institution of Oceanography) will analyze samples collected by others for nitrogen and neodymium isotopes, respectively. Tom Dickey (University of Southern California) is conducting optical measurements in collaboration with the NOAA TOGA/TAO long-term moorings. Pierre Flament (University of Hawaii) is processing the remote-sensing sea-surface temperature data. 
Richard Feely (Pacific Marine Environmental Lab.)

Rick Wanninkhof (Atlantic Oceanographic and Meteorological Lab.)

Don Atwood (Atlantic Oceanographic and Meteorological Lab.)

Robbie Toggweiler (Geophysical Fluid Dynamics Lab.)

Francisco Chavez (Monterey Bay Aquarium Research Institution)

Ken Buesseler (Woods Hole Oceanographic Institution)

Ed Peltzer (Woods Hole Oceanographic Institution)

Frank Millero (University of Miami)

Robert Byrne (University of South Florida)

Paul Quay (University of Washington)

Pat Wheeler (Oregon State University)
Total $\mathrm{CO}_{2}, \mathrm{PCO}_{2}$, hydrography

Total $\mathrm{CO}_{2}, \mathrm{PCO}_{2}$

Core nutrients

Natural ${ }^{14} \mathrm{C}$ distributions, basin-scale modeling

Primary productivity using ${ }^{13} \mathrm{C}$

Pigments, particulate carbon/nitrogen

${ }^{234}$ Th studies

Dissolved organic carbon

Alkalinity, $\mathrm{pH}$

Alkalinity, pH

Carbon isotopes

Nitrogen cycling and new productivity using ${ }^{15} \mathrm{~N}$ (Fall Cruises Only)

\section{Concluding Remarks}

The US-JGOFS Process Study described here is the result of a co-operative effort by the USJGOFS Steering Committee and members of the US ocean-sciences community. It is the result of a large number of meetings and workshops and is only one component of an International Equatorial Pacific Program (JGOFS 1990a,b). The field work will lead to an integrated understanding of equatorial ocean carbon and nitrogen cycles.

The issues of central equatorial Pacific productivity and carbon cycling involve the relationship of the biology and $\mathrm{CO}_{2}$ chemistry to predictive variables like sea-surface temperature and nutrient concentrations. The goal of EqPac is to understand the processes controlling the relationships so that we can parameterize and model primary and new productivity and their relationships to the structure of the biological food-web. The research plan should enable us to evaluate the relative importance of remote atmospheric winds, which regulate basin-wide upper-ocean heat storage, and local winds, which drive upwelling (Barber, 1990). With that understanding we will be able to construct predictive models of deep-ocean and benthic processes and decipher the long-term oscillations in the sedimentary record.

\section{Acknowledgements}

This research was supported by NSF Grant Numbers OCE9024379 (JWM) and OCE9022704 (MWL). This is University of Washington Contribution Number 1939. The US-JGOFS Executive Committee gave essential guidance and assistance during the planning and implementation of this project. The Oceanography reviewers helped provide focus for this article.

\section{References}

Archer. D.E., 1991: Equatorial Pacific calcite preservation cycles: production or dissolution? Paleoceanography: 6 . 561-571.

Bacastow, R. and E. Maier-Reimer, 1991: Dissolved organic carbon in modeling oceanic new production. Global Biogeochem. Cycles, 5, 71-85.
Banse, K., 1992: Grazing, temporal changes of phytoplankton concentrations, and the microbial loop in the open sea. In: Primary Productivity and Biogeochemical Cycles in the Sea. P.G. Falkowski and A.D. Woodhead, eds., Plenum Press, New York, 409-440.

Barber, R.T., 1988: Ocean Basin Ecosystems. In: Concept of Ecosystem Ecology. L.R. Pomeroy and J.J. Alberts, eds., Springer-Verlag, New York, 166-188.

, 1990: Ocean productivity and global carbon cycle. In: Preprint Volume of the Symposium on Global Change Systems. Special Sessions on Climate Variations and Hydrology, February 5-9, 1990, Anaheim, CA. American Meteorological Society, Boston, 18-21. , 1992a: Introduction to the WEC88 cruise: an investigation into why the equator is not greener. J. Geophys. Res., 97, 609-610.

1992b: Geological and climatic time scales of nutrient variability. In: Primary Productivity and Biogeochemical Cycles in the Sea. P.G. Falkowski and A.D. Woodhead, eds., Plenum Press. New York, 89-106.

and F.P. Chavez, 1991: Regulation of primary productivity rate in the equatorial Pacific. Limnol. Oceanogr., 36, 1803-1815.

and J.E. Kogelschatz, 1990: Nutrients and productivity during the 1982/1983 El Nino. In: Global Ecological Consequences of the 1982/1983 El Nino-Southern Oscillation. P.W. Glynn, ed. Elsevier, 21-53.

and J.H. Ryther, 1969: Organic chelators: factors affecting primary production in the Cromwell Current upwelling. J. Exp. Mar. Biol. Ecol., 3, 191-199.

Benner, R.. J.D. Pakulski. M. McCarthy, J.I. Hedges and P.G. Hatcher, 1992: Bulk chemical characterization of dissolved matter in the ocean. Science, 255, 1561-1564.

Chavez. F.P.. 1989: Size distribution of phytoplankton in the central and eastern tropical Pacific. Global Biogeochem. Cleles, 3, 27-35.

and R.T. Barber. 1987: An estimate of new production in the equatorial Pacific. Deep-Sea Res., 34. 12291243.

and R. Brusca, 1991: The Galapagos Islands and their relation to oceanographic processes in the tropical $\mathrm{Pa}$ cific. In: Galapages . Farne Invertebrates. M.J. James, ed. Plenum Press. New York. 9-33.

K.R. Buck and R.T. Barber, 1990: Phytoplankton taxa in relation to primary production in the equatorial Pacific. Deep-Sea Res., 37. 1733-1752.

Chisholm. S.W. and F.M.M. Morel. 1991: Preface: What controls phytoplankton production in nutrient-rich areas of the open ocean? Limnol Oceanogr., 36.

Cullen. J.J.. 1991: Hypotheses to explain high-nutrient conditions in the open sea. Limnol. Oceanugr., 36, 15781599.
The field work will

lead to an integrated

understanding of

equatorial ocean

carbon and nitrogen

cycles. 
Cullen, J.J., M.R. Lewis, C.O. Davis and R.T. Barber, 1992: Photosynthetic characteristics and estimated growth rates indicate grazing is the proximate control of primary production in the equatorial Pacific. J. Geophys. Res., 97, 630-654.

Cwienk, D. and M. Leinen, 1985: Expression of global sediment component fluxes in surface sediment accumulation rates. $E O S, 66,930$.

Dugdale, R.C. and J.J. Goering, 1967: Uptake of new and regenerated forms of nitrogen in primary productivity. Limnol. and Oceanogr., 12, 196-206.

Dymond J. and R. Collier, 1988: Biogenic particle fluxes in the equatorial Pacific: evidence for both high and low productivity during the 1982-1983 El Nino. Global Biogeochem. Cycles, 2, 129-137.

Enfield, D.B., 1989: El Nino, past and present. Rev. Geophys., 27. 159-187.

Eppley, R.W. and B.J. Peterson, 1979: Particulate organic matter flux and plankton production in the deep ocean. Nature, 282, 677-680.

Fasham, M.J.R., H.W. Ducklow and S.M. McKelvie, 1990: A nitrogen-based model of plankton dynamics in the oceanic mixed layer. J. Mar. Res., 48, 591-639.

Farrell, J.W. and W.L. Prell, 1989: Climate change and $\mathrm{CaCO}_{3}$ preservation: an 800,000 year bathymetric reconstruction from the central equatorial Pacific. Paleoceanography, 4, 447-466.

Feely, R.A., R.H. Gammon, B.A. Taft, P.E. Pullen, L.S. Waterman, T.J. Conway, J.F. Gendron and D.P. Wisegarver, 1987: Distribution of chemical tracers in the eastern equatorial Pacific during and after the 19821983 El Nino-Southern Oscillation event. J. Geophys. Res., 92, 6545-6558.

Feldman, G., J.W. Murray and M. Leinen, 1992: EqPac planning: applications of Pacific CZCS data. Oceanography, $5,143-145$.

Frost, B.W. and N.C. Franzen, 1992: Grazing vs. iron limitation in the control of phytoplankton stock and nutrient concentration: a chemostat analogue of the Pacific equatorial up-welling zone. Mar. Ecol. Prog. Ser., 83, 291 303.

Gammon, R.H., E.T. Sundquist and P.J. Fraser, 1985: History of carbon dioxide in the atmosphere. In: Atmospheric Carbon Dioxide and the Global Carbon Cycle. J.R. Trabalka, ed., DOE/ER-0239, United States Department of Energy, Washington, D.C., 25-62.

Halpern. D. and H.P. Freitag, 1987: Vertical motion in the upper ocean of the equatorial Eastern Pacific. Oceanol. Acta, Vol. Spec. No. 6, 19-26.

JGOFS, 1990a: Report of the JGOFS Pacific Planning Workshop, Honolulu, HI, September, 1989 Report No. 3, JGOFS, Scientific Committee for Ocean Research, $69 \mathrm{pp}$.

JGOFS, 1990b: Report of a Workshop on equatorial Pacific Process Studies, Tokyo, April 1990, Report No. 8, JGOFS, Scientific Committee for Ocean Research, $75 \mathrm{pp}$.

Keeling, C.D., 1968: Carbon dioxide in surface ocean waters. 4. Global distribution. $J$ Geophvs. Res.. 73, 4543-4553.

Leinen, M.W. and J.W. Murray, 1990: A Rationale and Plan for U.S. Joint Global Ocean Flux Studies in the Central Equatorial Pacific. US JGOFS, $37 \mathrm{pp}$.

Lyle, M., D.W. Murray, B.P. Finney, J. Dymond, J.M. Robbins and K. Brooksforce, 1988: The record of late Pleistocene biogenic sedimentation in the eastern tropical Pacific Ocean. Paleoceanography, 3, 39-59.

Martin, J.H. and S.E. Fitzwater, 1992: Dissolved organic matter in the Atlantic, Southern, and Pacific Oceans. Nature, $356,699-700$.
R.M. Gordon, S. Fitzwater and W.W. Broenkow, 1989: VERTEX: phytoplankton/iron studies in the Gulf of Alaska. Deep Sea Res., 36, 649-680.

Martin, W.R., M. Bender, M. Leinen and J. Orchardo, 1991 : Benthic organic carbon degradation and biogenic silica dissolution in the central equatorial Pacific. Deep Sea Res., 38, 1481-1516.

Miller, C.B., B.W. Frost, P.A. Wheeler, M.R. Landry, N. Welschmeyer and T.M. Powell, 1991: Ecological dynamics in the subarctic Pacific, a possibly iron-limited ecosystem. Limnol. Oceanogr., 36, 1600-1615.

Mitchell, B.G., E.A. Brody, O. Holm-Hansen, C. McClain and J. Bishop, 1991: Light limitation of phytoplankton biomass and macronutrient utilization in the Southern Ocean. Limnol. Oceanogr., 36, 1662-1677.

Murphy, P.P.., R.A. Feely, R.H. Gammon, D.E. Harrison. K.C. Kelly and L.S. Waterman, 1991: Assessment of the airsea exchange of $\mathrm{CO}_{2}$ in the south Pacific during austral autumn. Journal of Geophysical Research, 96, 20, 455465.

Murray, J.W., J. Downs, S. Strom, C-L Wei and H. Jannasch, 1989: Nutrient assimilation, export production and ${ }^{234} \mathrm{Th}$ scavenging in the eastern Equatorial Pacific. Deep Sea Res., 36, 1471-1489.

Najjar, R.G., J.L. Sarmiento and J.R. Toggweiler, 1992: Downward transport and fate of organic matter in the ocean: simulations with a general circulation model. Global Biogeochem. Cycles, 6, 45-76.

Pedersen, T.F., 1983: Increased productivity in the eastern equatorial Pacific during the last glacial maximum (19,000 to 14,000 yr B.P.). J. Geol., 11, 16-19.

Pena. M.A., M.R. Lewis and W.G. Harrison, 1990: Primary productivity and size structure of phytoplankton biomass on a transect of the equator at $135 \mathrm{~W}$ in the Pacific Ocean. Deep Sea Res., 37, 295-315.

Philander, S.G.H., W.J. Hurlin and A.D. Seigel, 1987: Simulation of the seasonal cycle of the tropical Pacific Ocean. J. Phys. Oceanogr., 17, 1986-2002.

Pisias, N.G. and D.K. Rea, 1988: Late Pleistocene paleoclimatology of the central equatorial Pacific: sea surface response to the southeast trade winds. Paleoceanography, 3, 21-37.

Price, N.M., L.F. Andersen and F.M.M. Morel, 1991: Iron and nitrogen nutrition of equatorial Pacific plankton. Deep Sea Res., 38, 1361-1378.

Siegenthaler, U., 1990: El Nino and atmospheric $\mathrm{CO}_{2}$. Nature, 345, 295-296.

Smith, C.R., 1992: Factors controlling bioturbation in deepsea sediments and their relation to models of carbon diagenesis. In: Deep-Sea Food Chains and the Global Carbon Cvcle, G.T. Rowe and V. Pariente, eds., Kluwer Academic Publishers, Netherlands. 375-393.

Thomas, W.H., 1979: Anomalous nutrient chlorophyll interrelationships in the off-shore eastern tropical Pacific Ocean. J. Mar. Res., 37, 327-335.

US GOFS, 1986: Report of the US GOFS Steering Committee on plans for the North Atlantic GOFS Pilot Program. US GOFS Planning Office, Woods Hole, MA, $141 \mathrm{pp}$.

US GOFS, 1989: Report of the US JGOFS 3rd Pacific Planning Meeting. Report No. 9, US GOFS Planning Office, Woods Hole, MA, 192 pp.

US JGOFS, 1990: U.S. Joint Global Ocean Flux Study Long Range Plan, The Role of Ocean Biogeochemical Cycles in Climate Change. Report No. 11. US JGOFS Planning Office, Woods Hole, MA, 216 pp.

Walsh, J.J., 1976: Herbivory as a factor in patterns of nutrient assimilation in the sea. Limnol. Oceanogr., 21 , $1-13$. 